\title{
THE RISK PERCEPTIONS OF INDIVIDUAL INVESTORS*
}

\author{
Chris Veld \\ Corresponding author. Department of Accounting and Finance, University of Stirling, \\ Stirling FK9 4LA, United Kingdom. Tel: +44 1786 467309; Fax: +44 1786 467308; e- \\ mail: c.h.veld@stir.ac.uk \\ Yulia V. Veld-Merkoulova \\ Department of Accounting and Finance, University of Stirling, Stirling FK9 4LA, United \\ Kingdom. Tel: +44 1786 466417; Fax: +44 1786 467308; e-mail: j.w.veld- \\ merkoulova@stir.ac.uk
}

May 31, 2007

\footnotetext{
* The authors thank Vera Toepoel for her help with the CentERpanel, and Marcel Das, Abe de Jong, Frans de Roon, Sean Finucane, Octavian Ionici, Arie Kapteyn, Wieland Müller, Christophe Perignon, Ailsa Röell, Jenke ter Horst, participants in the workgroup on Behavioral and Experimental Economics at Tilburg University, seminar participants at Tilburg University, participants at the Conference of the Northern Finance Association in St. Johns, Newfoundland (September 2004), at the Southern Finance Association in Key West (November 2005), and at the Scottish Economic Society in Perth (April 2007) for helpful comments and suggestions. Special thanks go to three anonymous referees, Erich Kirchler (the Associate Editor), and Bas Donkers for their helpful comments and suggestions. The financial support of the Dutch Science Organization (NWO; A laboratory for the use of household financial decisions) and of the President's Research Fund of Simon Fraser University (Chris Veld) is gratefully acknowledged. Part of the research for this project was done while Chris Veld was employed at Tilburg University in the Netherlands and at Simon Fraser University in Canada and while Yulia Veld-Merkoulova was at the Faculty of Management of the Erasmus University in Rotterdam. The usual disclaimer applies.
} 


\title{
THE RISK PERCEPTIONS OF INDIVIDUAL INVESTORS
}

\begin{abstract}
Risk perceptions of individual investors are studied by asking experimental questions to 2,226 members of a consumer panel. Their responses are analyzed in order to find which risk measures they implicitly use. We find that most investors implicitly use more than one risk measure. For those investors who systematically perceive risk according to the same risk measure, semi-variance of returns is most popular. Semi-variance is similar to variance, but only negative deviations fro the mean or another benchmark are taken into account. Stock investors implicitly choose for semi-variance as a risk measure, while bond investors favor probability of loss. Investors state that they consider the original investment to be the most important benchmark, followed by the risk-free rate of return, and the market return. However, their choices in the experimental questionnaire study reveal that the market return is the most important benchmark.
\end{abstract}

Keywords: individual investors, risk profile, variance, downside risk measures, shortfall, semi-variance, experimental questionnaire study

JEL-codes: G11, G12 
In the last five years there has been an increasing attention in the investment profession for the risk attitudes of individual investors. This attention is partly caused by declining stock prices around the turn of the millennium. In the context of investment advice to individual investors, financial institutions all over the world have started to use so-called risk profiles of their clients. These risk profiles are standard questionnaires that are completed by potential clients. Risk profiles used by different banks in different countries all have in common that they contain questions on both the time horizon of the investors and on their risk perceptions. ${ }^{1}$ The idea behind the questions on the time horizon is that investors with a longer time horizon would generally be better off investing in stocks compared to investors with shorter time horizons. ${ }^{2}$ The questions on the risk perceptions include questions such as "Assume that over the last year your diversified portfolio of stocks declined by $20 \%$. How would you react"? The possible answers generally vary between "I would sell my stocks immediately" to "I would hold on to my portfolio for at least another year". The obvious idea behind the questions on the risk perceptions is that investors who are more risk tolerant would benefit from relatively larger investments in stocks. The combined score on the time horizon and the risk perception questions leads to an investment advice on the asset allocation for the potential client. In the Netherlands, financial institutions are legally obliged to construct such risk profiles. In other countries, they are generally not compulsory.

\footnotetext{
${ }^{1}$ This is for example the case for risk profiles used by financial institutions in Canada, the Netherlands, New Zealand, and the United States.

${ }^{2}$ The concept that a longer time horizon should lead to a larger allocation to shares has long been disputed by finance theorists. This was based on the idea of Merton [1969] that if asset returns are i.i.d., an investor with power utility who rebalances her portfolio optimally, should choose the same asset allocation, regardless of investment horizon. However, research by Barberis [2000] shows that investors with longer time horizons should invest more in equity than investors with short time horizons. This is based on the finding that stock returns exhibit mean-reversion, which lowers the variance of cumulative returns over long horizons.
} 
An interesting question in this context is how risk should be measured. Standard textbooks in finance and investment generally teach that risk is measured as the variance of (portfolio) returns. ${ }^{3}$ This is a symmetric risk measure in which upwards deviations from the mean are given as much weight as downwards ones. However, there is also some limited evidence that in reality investors tend to find downside risk to be more important. For example, Unser [2000] finds that measures of shortfall risk are more important than the variance of returns. In line with this we see that in the behavioral finance literature it is documented that investors are more sensitive to losses than to gains. Empirical research by Kahneman, Knetsch, and Thaler [1990] and Tversky and Kahneman [1992] shows that losses are weighted about twice as strongly as gains. The disutility of losing $\$ 100$ is roughly twice the utility of gaining $\$ 100 .^{4}$ This feature, which is generally referred to as loss aversion, stems from prospect theory and was documented by Kahneman and Tversky [1979]. ${ }^{5}$ Barberis and Huang [2001] find that loss aversion over the individual stock returns can help explain high and volatile stock returns observed on the market.

In this paper we study how individual investors perceive risk by asking experimental questions to members of a Dutch investor panel. We consider three asymmetric risk measures. The first one is the semi-variance. This risk measure is similar to the variance, but it only takes the deviations below the target return into account. The second and third risk measures are the probability of loss, and the expected value of loss.

\footnotetext{
${ }^{3}$ See e.g. Bodie, Kane, and Marcus [2002], or Ross, Westerfield, and Jaffe [2005].

${ }^{4}$ The impact of loss aversion on optimal portfolio choice is studied, for example, by Berkelaar, Kouwenberg, and Post [2004].

${ }^{5}$ A well-studied case of loss aversion is myopic loss aversion. This combines loss aversion, and a tendency to evaluate outcomes frequently. Investors who display myopic loss aversion are less willing to invest a greater portion of their wealth into risky assets if they evaluate their investments too frequently. See Thaler, Tversky, Kahneman, and Schwartz [1997], Gneezy and Potters [1997], Gneezy, Kapteyn and Potters [2003], Haigh and List [2005], and Bellemare, Krause, Kröger, and Zhang [2005].
} 
All these asymmetric risk measures are special cases of the $\alpha$-t model of Fishburn [1977].

The fourth risk measure that we test is the variance of returns, which is a symmetric risk measure.

The way in which investors perceive risk is studied by submitting a questionnaire to members of the CentERpanel of CentERdata, which is associated with Tilburg University in the Netherlands. This consumer panel contains approximately 3,000 members of 2,000 representative Dutch households. We ask them direct questions on a number of topics that are related to their investments. For example, we ask them which financial instruments they hold, what their investment horizon is, and what their benchmark is. The second part of the questionnaire contains experimental questions in the form of pairwise comparisons. In these questions we ask the respondents to choose between two ways to invest 1,000 euro that both have the same expected return, but that are different with regard to risk. The questions are constructed in such a way that the first alternative is less risky according to one risk measure, and the second alternative is less risky according to the other three risk measures. We find that in three out of four questions, most respondents have a preference for the alternative that is less risky according to the three risk measures. ${ }^{6}$ Our results show that the respondents implicitly base their decisions on more than one risk measure. A subgroup of respondents systematically chooses the same risk measure. Within this group, semi-variance is the most popular risk measure, preferred by $48 \%$ of the respondents. Semi-variance is followed by probability of loss (20\%), variance (18\%), and expected value of loss $(14 \%)$.

\footnotetext{
${ }^{6}$ The only exception is for the question in which the respondents are asked to choose between the alternative with the lower semi-variance, and the alternative that is less risky according to the other three risk measures. Here the answers are equally divided between the two alternatives.
} 
The results also show that stock investors have a preference for semi-variance as a risk measure, while bond investors prefer probability of loss.

Another remarkable result is that there seems to be a large divergence between the benchmark that investors indicate themselves and the benchmark that implicitly results from their choices. When asked directly, investors indicate that they consider the original investment to be the most important benchmark (59\%), followed by the risk-free rate of return $(28 \%)$, and the market return $(7 \%)$. If, on the other hand, their choices in the experimental questions are analyzed, a completely different picture emerges. In this case the market return is the most popular benchmark $(40 \%)$, followed by the initial investment (29\%), and the risk-free rate of return (18\%).

We have also tested whether the answers to the experimental questions are related to demographics of the respondents. The only systematic pattern that we find is that respondents in a number of demographic categories are more likely to answer that they are indifferent or that the question is not clear for them. More specifically, respondents that are younger, male, have followed university or college education, or who earn more than 2,000 euro per month, are more likely to make a choice between the investment alternatives rather than indicating that they are indifferent or that the question is not clear for them. These differences largely disappear when we only look at the sub-sample of investors. In that case only the gender difference holds.

Finally, we have also used a questionnaire that was identical to the first, except that all amounts are multiplied by 20 . The results from this questionnaire are generally the same as the results from the first questionnaire. The only differences are the fact that investors now choose in all four questionnaires for the alternative that is less risky 
according to the three risk measures, and that the zero return is slightly favored as a benchmark (33\%), over the market return (32\%), and the risk-free rate or return $(14 \%)$.

These results are potentially very useful for financial institutions that use questionnaires in order to measure the risk perceptions of their customers.

The remainder of this paper is organized as follows. Section I describes theoretical concepts of risk. The experimental questionnaire study is described in Section II. The results of the experimental questionnaire study are described in Section III. The paper is concluded in Section IV.

\section{Theoretical concepts of risk}

A large part of the modern investment theory is based on the mean-variance framework. In this framework the variance of the investor's portfolio returns is the most important risk measure. ${ }^{7}$ The advantage of this approach is that investment decisions are only based on the mean and the variance of returns. An important disadvantage of this approach is that the variance is symmetrical. This means that it assigns the same weight to positive and to negative deviations from the expected value. In other words, variance does not capture the common notion of risk as a negative, undesired risk.

There is also a strand of literature that uses measures of risk that only look at the downside of risk. The first paper in this field is by Roy [1952] who proposes a safety-first model in which return is traded off against the risk of earning less than a target or minimum acceptable return. Other applications of downside risk models are the model of

\footnotetext{
${ }^{7}$ It should be emphasized that the variance is the relevant risk measure for the entire portfolio. The relevant risk measure for an individual asset is different. For example, in the Capital Asset Pricing Model, which is based on mean-variance analysis, the relevant risk measure of an individual asset is the beta. This is the covariance of the asset return with the return on the market portfolio divided by the variance of the returns on the market portfolio.
} 
Bodie [1991], who uses shortfall risk measures in the context of pension fund management, Leibowitz and Kogelman [1991], who develop a simple shortfall methodology to determine the division between risky and riskless assets in a portfolio, and the model of Milevsky, Ho, and Robinson [1997], who study the optimal consumption in retirement. De Bondt [1998], Unser [2000], and Bertsimas, Lauprete, and Samarov [2004] argue that investors rather base their decisions on measures of shortfall than on the variance of returns.

Fishburn [1977] develops a mean-risk dominance model with risk associated with below target returns. These are measures of downside or shortfall risk in the sense that only negative deviations from a target are taken into consideration. This model is generally referred to as the $\alpha$-t model. Fishburn describes the "riskiness" of a below-thetarget outcome as its distance from the target, weighted by the parameter $\alpha$. His measure for risk is defined as

$$
F_{\alpha}(t)=\int_{-\infty}^{t}(t-x)^{\alpha} d F(x)
$$

Where:

$\mathrm{t}=$ the target return;

$\alpha=$ a parameter that measures the importance of large deviations from the target relative to the small ones;

$\mathrm{F}(\mathrm{x})=$ the probability distribution of portfolio returns.

There are three special cases of the $\alpha$-t model. The first is the probability of loss $(\alpha=0)$. This is the probability that an investor makes a return below the target. The second is the expected value of loss $(\alpha=1)$. This is equal to the probability of a belowthe-target return times the magnitude of deviation from the target. The third is the semi- 
variance $(\alpha=2)$. The last mentioned risk measure, which was already proposed in the seminal work of Markowitz [1959], is similar to the variance, but it only takes the deviations below the target return into account.

The objective of this paper is to study which risk measure individual investors (implicitly) base their decisions on. The first risk measure that we consider is the variance of returns, which is a symmetric risk measure. In addition, we study the three special cases of the $\alpha$-t model mentioned above. ${ }^{8}$

\section{The experimental questionnaire study}

The experimental questionnaire study in this paper is based on a questionnaire submitted to the panel of CentERdata at Tilburg University in the Netherlands. ${ }^{9}$ This internet-based panel consists of approximately 3,000 members from approximately 2,000 households. However, there is no need to have a personal computer with an Internet connection. Households that do not have access to the Internet are provided with a socalled NetBox with which a connection to the Internet can be established via a telephone line and a television set. All households can call a helpdesk or ask for technical support from home. The panel is recruited by telephone, so the recruiting of the panel is independent of whether or not households have Internet access. The panel is kept representative of the Dutch population with respect to a number of demographics. In other words, the average panel member has the same experiences and knowledge as the

\footnotetext{
${ }^{8}$ A possible alternative is to look at higher moments rather than only at the first two moments. However, Samuelson [1970] and Bodie et al. [2002] conclude that higher moments are not relevant for portfolio decisions.

${ }^{9}$ CentERdata is a survey research institute, specializing in Internet-based surveys. These surveys are carried out through the CentERpanel. CentERdata is located at Tilburg University in the Netherlands. Information about CentERdata and the CentERpanel can be found at http://www.centerdata.nl
} 
average person living in the Netherlands. The members of the panel are interviewed each week on a number of issues that mostly deal with financial matters. Clients of the panel are businesses and university researchers. ${ }^{10}$ An important advantage of the use of the panel is that it has a number of demographic variables available for all participants. These may be linked to the answers that the respondents give.

We originally created the questionnaire in English, but the version sent to the respondents was translated in Dutch by one of the authors of this paper. ${ }^{11}$ The final version of the questionnaire was not pre-tested on a separate sample. However, we have held a number of discussions with the staff at CentERdata to make sure that the questions would be clear for the members of the panel. The appendix contains an accurate translation of the version that was submitted by internet to the respondents.

The members of the CentERpanel are first asked to make several sequential choices between two possible investment alternatives. The alternatives all have the same expected returns, but they are different in their volatility and/or downside risk. Therefore, the investors optimize their utility by choosing the alternative with the lowest perceived risk. The use of pairwise comparisons is standard in economic experiments and is frequently used to test expected utility and its generalizations. ${ }^{12}$

\footnotetext{
${ }^{10}$ The panel has been used for previous finance research. For example, Dong, Robinson, and Veld [2005] study preferences of individual investors on dividend payments, and Guiso, Sapienza, and Zingales [2007] investigate the relationship between trust and stock market participation.

${ }^{11}$ The Dutch version of the questionnaire is, on request, available from the authors.

${ }^{12}$ The many examples include Harless and Camerer [1994], Hey and Orme [1994], and Holt and Laury [2002]. See Camerer [1995] for an overview.
} 
The first four questions are set up in such a way that Alternative 1 minimizes one risk measure and Alternative 2 minimizes the other three risk measures. ${ }^{13}$ This can be illustrated with Question 1. This question reads:

"Suppose that you plan to invest 1,000 euro of your own money in an investment fund. You can choose between 2 investment funds. Both funds will be liquidated after 1 year and on average they pay out 1,100 euro (this is a return of $10 \%$, which is equal to the average return on the stock market). The payment at the end of the year is unknown. You have the following probabilities of receiving different payments from the funds. What do you choose?

1. Fund A: $10 \%$ chance of 200 euro, and $90 \%$ chance of 1,200 euro

2. Fund B: $40 \%$ chance of 920 euro, and $60 \%$ chance of 1,220 euro

3. Both choices are equally attractive (or unattractive) to me

4. The question is not clear for me"

In Panel A of Table $\mathrm{I}$ it is demonstrated that Alternative 1 will be chosen by respondents who are mostly concerned about the probability of loss.

\section{[Please insert Table I here]}

This probability is only 10 percent in Alternative 1 and it is 40 percent in Alternative 2. According to the other three risk measures, Alternative 2 is less risky than Alternative 1. ${ }^{14}$ In Questions 2 to 4 , Alternative 1 will be chosen by respondents who are mostly concerned about respectively, semi-variance, expected value of loss, and variance.

\footnotetext{
${ }^{13}$ It should be noted that the order of the questions is not randomized. In principle, this could lead to an anchoring effect, where respondents have a tendency to rely too heavily ("anchor") on one trait or piece of information (see Tversky and Kahneman, 1974). However, we believe that this effect is especially serious for "open" questions where respondents have to formulate their own answer. In our study, we use multiple choice questions, where we expect this effect to be less important.

${ }^{14}$ The expected value of loss of alternative 1 is $0.1 * 800$ is 80 , while it is only $0.4 * 80$ is 32 for alternative 2 . The variance of returns in alternative 1 is $0.1 *(-80-10)^{2}+0.9 *(20-10)^{2}$ is $900 \%$. The standard devation is the square root of this, which is $30 \%$. Similarly the variance of alternative 2 is $0.4 *(-8-10)^{2}+0.6 *(22-10)^{2}$ is $216 \%$. The standard devation is the square root of this, which is $14.7 \%$. The semi-variance of returns in alternative 1 is $0.1 *(-80-0)^{2}=640 \%$. The semi-variance of alternative 2 is $0.4 *(-8-0)^{2}=25.6 \%$. Note that
} 
The questions are constructed in such a way that the mean return for each alternative is $10 \%$. This mean number is also given to respondents in each question. This number is based on the fact that the real return on U.S. stocks over the period 1926-1999 was 10 percent (see Chapter 5 of Bodie et al. [2002]). ${ }^{15}$ Furthermore the alternatives are calibrated in such a way that the standard deviation lies between 14 and 26 percent. This range is chosen because the standard deviation of (nominal) returns for U.S. stocks was 20 percent over the same period (see also Bodie et al. [2002]). In order to avoid alternatives with odd numbers, we have rounded off numbers in such a way that the expected return is always between 9.9 and 10.1 percent and the standard deviation is always between 14 and 30 percent.

The next step is to find out what is the benchmark (or target return in the $\alpha-t$ model) for the respondents who choose one of the asymmetric risk measures. This benchmark can either be the initial investment, the risk-free rate of return, or the market rate of return. The choice for the benchmark is examined in Questions 5-8. These questions are offered to the respondents who previously (implicitly) revealed that they find asymmetric risk important. For example, Questions 5 and 6 have to be answered by all respondents who answered "1" to either Question 1 or Question 3. By giving this answer they indicate a preference for the probability of loss (Question 1) and/or the expected value of loss (Question 3). Question 5 reads:

"Suppose that you plan to invest 1,000 euro of your own money in an investment fund. You can choose again between two funds. Both funds will be liquidated after 1

Table I gives the values of asymmetric risk measures with a target return equal to 0 . Although the values will change if we set the target return equal to $10 \%$, the ranking of the alternatives remains the same for Questions 1 to 4 .

${ }^{15}$ To be precise the average nominal return on large stocks was $13.11 \%$. The inflation rate over the same period was $3.17 \%$. 
year, and on average they pay out 1,100 euro (this is a return of $10 \%$ ). This average return is higher than the interest on a savings account. A savings account would have paid 1,040 euro with certainty (this is a return of $4 \%$ ). You can use the interest on the savings account in order to make a comparison. It is not possible to put the 1,000 euro in a savings account. What do you choose?

1. Fund A: $10 \%$ chance of 680 euro, $5 \%$ chance of 1,050 euro, and $85 \%$ chance of 1,150 euro

2. Fund B: $5 \%$ chance of 730 euro, $70 \%$ chance of 1,050 euro, and $25 \%$ chance of 1,310 euro

3. Both choices are equally attractive (or unattractive) to me

4. The question is not clear for me"

In Panel B of Table I it is demonstrated that Alternative 1 is preferable if the market return is the benchmark, and Alternative 2 is preferable if the initial investment or the risk-free rate of return is the benchmark. Question 6 is set up in such a way that Alternative 1 is chosen by respondents who have a preference for the risk-free rate of return or the market return as the benchmark, and Alternative 2 is preferable for investors who have the initial investment as a benchmark. Based on the combination of these responses it is possible for us to determine their benchmark. Questions 7 and 8 have to be answered by the respondents who answered "1" as an answer to Question 2. Panel A of Table I shows that by answering " 1 " they indicate a preference for the semi-variance as a risk measure. Panel $\mathrm{C}$ of Table I compares the semi-variance of the alternatives for different target returns. Questions 7 and 8 are set up in a similar way to Questions 5 and 6. Based on the answers to these questions we can determine whether the investors consider the semi-variance relative to zero, the risk-free rate, or the market return.

The experimental questionnaire study is not incentive-induced. Even though it can be argued that a financial stimulus will motivate the subjects to think more deeply about 
their choices, there are important reasons not to reward them. The first reason is that we want people to consider the alternatives as if they were investing their own money. By awarding people for their choices, we create an endowment effect. ${ }^{16}$ Besides that, we want people to think in terms of substantial amounts of money. This is virtually impossible in an incentive-induced experiment, simply because it would get too costly. A solution that is often chosen for the second problem is to give all the participants a chance to win their choice. In such a case, one person would be allowed to play the game of her choice. However, Rabin [2000] argues that this lottery procedure is known to only be sufficient when the expected-utility hypothesis is maintained. Since in this paper we are testing the implications from this hypothesis against competing hypotheses, this procedure would not be useful for our purpose. ${ }^{17}$ In addition, Camerer [1995] argues that persons with well-formed preferences are likely to express these truthfully, whether they are paid or not. ${ }^{18}$

In the second part of the experimental questionnaire study we ask questions similar to the first part. We only multiply all the amounts by 20 . The first experimental questionnaire study carries the risk that investors consider the 1,000 euro mentioned in that questionnaire as a marginal investment. Since they might take different decisions when their whole capital is at stake, we have added this second part. The questions in this second part are phrased in the following way: "You are planning to allocate 20,000 euro of your own money in a stock investment fund. This is all the money you want to invest

\footnotetext{
${ }^{16}$ See Kahneman, Knetsch, and Thaler [1990] for a discussion of the endowment effect.

${ }^{17}$ Rabin [2000] also argues that if expected-utility theory holds, these procedures are at best redundant, and are probably harmful.

${ }^{18}$ Harless and Camerer [1994] find that the main effect of paying subjects is a reduction in the variance of their responses. This bias is avoided by not paying the subjects.
} 
in stocks. You are planning to keep the rest of your savings on a savings account. You are considering two funds that offer the following payouts after one year (...)".

The third part of the experimental questionnaire study consists of Questions 9 to 17 from the appendix. These are questions in which background information on the investors is acquired. In this part we ask questions on the type of financial instruments that they hold, on their time horizon, and on their benchmark.

\section{Results}

\section{A. Investment products}

The first and the third part of the questionnaire were presented to the 2,943 members of the panel of CentERdata on the weekend of November 28, 2003. ${ }^{19}$ These members had the opportunity to fill out the questionnaire from 17.00 hours on Friday November 28, 2003 to 24.00 hours on Tuesday December 2. In total 2,226 respondents filled out the questionnaire (75.6\%). This makes the number of non-respondents equal to 717. The second part of the questionnaire was presented to the panel from 17.00 hours on Friday December 5, 2003 to 24.00 hours on Tuesday December 9. This part of the questionnaire was answered by 2,126 of a total of 2,962 respondents $(71.8 \%)$.

We first present the results on the financial products that the respondents own or have owned in the prior three years. These results are presented in Table II.

[Please insert Table II here]

In total 1,629 respondents indicate that they own investment products. We find that $17.5 \%$ of these panel members own stocks of exchange-listed companies other than

\footnotetext{
${ }^{19}$ For this purpose all panel members of 16 years and older were selected. This allows the possibility that multiple persons from one household answer the questionnaire. This does not cause a problem for our research since we ask for risk attitudes. These can be different among household members.
} 
investment funds. Stocks of investment funds are held by $36.4 \%$ of the panel members. Besides that, a relatively large part of this panel holds indirect investment in stocks. The most common indirect investments in stocks are stocks in life annuities (17.2\%), and investment mortgages (12.0\%). In a life annuity the individual pays part of her income to a life insurance company. The contribution is deducted from income for tax purposes in the year it is paid to the insurance company. The contribution is invested by the insurance company. At the end of the maturity the individual is obliged to use the proceeds in order to buy a life annuity in order to supplement her pension. The payments from the life annuity are taxable. The investment mortgage is a combination of a mortgage loan and an investment. Individuals pay interest on the mortgage loan, but do not repay this loan until the end of the maturity (usually 30 years). Instead they contribute to a life insurance. This contribution is invested in stocks, bonds, and/or stocks in investment funds. At the maturity, the proceeds of the life insurance are used to pay off the principal amount of the mortgage. This system is very popular for tax reasons.

Not surprisingly, $88.5 \%$ of the panel members who indicate that they hold investment products, state that they have at least one savings account. The remaining investment products are only held by a small part of the panel members who indicate that they have invested in financial products.

In the remainder of this paper we distinguish between "investors" and "noninvestors". With regard to investors we want to limit ourselves to persons who actively invest in risky assets. For this reason we do not count persons who only have investments in life annuities and/or in investment mortgages as investors. We also do not count individuals who only have savings accounts as investors. 


\section{B. Risk measures}

The summary results of the first part of the experimental questionnaire study are included in Table III. These results are for the investors in our sample. ${ }^{20}$

[Please insert Table III here]

For each question we document the number of answers. Alternative 1 corresponds to Answer 1. Alternative 2 corresponds to Answer 2, and Answers 3 and 4 correspond to respectively "equally (un)attractive", and "the question is not clear". In the second part of the table we exclude Answers 3 and 4, and we calculate means and medians.

The results for the investment of 1,000 euro, from now on to be referred to as the marginal investment, are presented in Panel A of Table III. In Question 1 we find that $28.64 \%$ of the respondents find the probability of loss to be more important than the other three risk measures. If Alternatives " 3 " and " 4 " are eliminated, this percentage increases to $36.51 \%$. Both the mean and the median are significantly different from 1.5 , thereby indicating that the majority of the respondents find other risk measures to be more important than the probability of loss. The answers to Questions 3 and 4 also indicate that Alternative " 2 " is significantly more popular than Alternative " $1 "$ " In each of the Questions 1-4, between 30 and 51 percent of the respondents choose a specific risk measure. The remaining 49 to 70 percent prefer an alternative that is minimizing the other three risk measures. In 3 out of 4 questions, this proportion is significantly different from $50 \%$. The answers are, therefore, not random. This evidence also suggests that there

\footnotetext{
${ }^{20} \mathrm{We}$ also have results for the whole sample. Since these are virtually the same as the results for the investors, we restrict ourselves to presenting the results for the investors. The results for the whole sample are, on request, available from the authors.
} 
is no single risk measure that is preferred by the majority of investors. Rather, all four risk measures are important, with semi-variance being chosen by about 50 percent of respondents. We can also look at the total percentage of respondents who choose a single risk measure against the other three. If every investor had one and only one risk measure, we would expect the percentage of investors in the first four rows of column (7) to add up to 100 . However, the actual number it adds up to is $156 \%$. This indicates that a single investor considers a number of important risk characteristics. A preliminary conclusion that can be drawn from these results is that investors use several risk measures. However, the semi-variance is more popular than the other three risk measures.

The answers to Question 5 indicate that $48.20 \%$ of the respondents, who are concerned with either the probability of a loss or the expected value of a loss, consider underperformance relative to the market return. The remaining $51.80 \%$ relate this underperformance to either the risk-free rate of return or the initial investment (zero return). Question 6 shows that $51.27 \%$ of the respondents find the risk-free rate of return or the market return to be more important than the initial investment (zero return).

Questions 7 and 8 are for respondents who indicated earlier that they are concerned about the semi-variance. The answers to Question 7 show that significantly more of these respondents relate the semi-variance of returns to the market return than to the risk-free rate of return or the zero return. Apparently this group of investors sees the market return as an important benchmark. This result is confirmed, or in any case not contradicted, in Question 8 where $63.74 \%$ of the respondents indicate that they find the market rate of return and the risk-free rate of return to be more important than the zero return. 
A further analysis of the answers to Questions 1-4 is presented in Figure I. In this figure we left out all the results for respondents who answered at least once " 3 " or " 4 " in Questions 1 to 4 . This means that we kept only the 449 respondents who made a choice in all four questions for one of the investment alternatives (Alternative 1 or 2).

[Please insert Figure I here]

Figure I starts with the answer to Question 4 in Panel A of Table III. Respondents, who answered "1" here, implicitly see the variance as their most important risk measure. Those who choose "2" implicitly choose one or more of the asymmetric risk measures, which are all special cases of the $\alpha$-t model. The reason that we start with the answers to Question 4 is that the variance is the only symmetric risk measure in our research. As can be seen in Figure I, in total $42.09 \%$ of the respondents choose variance, the remaining $57.91 \%$ chooses for the other (asymmetric) risk measures. ${ }^{21}$ In the next nod we check whether the investors who choose variance as a risk measure in Question 4, have also chosen one of the asymmetric risk measures in any of the other questions. This turns out to be the case for $85.19 \%$ of these respondents. Of these investors, semi-variance is most popular, followed by probability of loss. With regard to the investors who do not consider the variance to be the most important risk measure, $84.62 \%$ has chosen for an asymmetric risk measure in one of the preceding questions. Also for these investors, semi-variance is the most important risk measure, now followed by expected value of loss.

An important conclusion that can be drawn from Figure I is that almost $58 \%$ of the investors do not consider the variance to be the most important risk measure. This is remarkable, since a large part of the investment theory is based on the variance as the

\footnotetext{
${ }^{21}$ The results from Figure I do not exactly match those of Question 4 in Panel A of Table III. The reason for this is that in Figure I we left out all the respondents who answered at least once "3" or " 4 " in one of the Questions 1-4.
} 
only risk measure. Even among the investors who do choose variance, more than $85 \%$ also finds at least one of the asymmetric risk measures to be important. This means that only 28 out of 449 investors $(6 \%)$ systematically choose the variance as the most important risk measure. Finally, both classes of investors who choose the variance and those that do not choose the variance tend to find the semi-variance to be the most important asymmetric risk measure.

As mentioned before, we have asked the same questions for a much larger investment (20,000 euro instead of 1,000 euro). These results are labeled as the results for the total investment. The answers to these questions are presented in Panel B of Table III. The results for Questions 1, 3, and 4 are not noticeably different between Panel A and Panel B. There is a difference however between the results of Question 2. In Panel A we find an almost equal number of investors answering " 1 " as answering "2", indicating an equal preference for semi-variance as for the other risk measures. This preference has mostly disappeared in Panel B. The result for semi-variance considered in isolation is still better than that of the other risk measures $(42.83 \%$ versus $36.05 \%$ for probability of loss, which is the second most popular risk measure considered in isolation), but it is significantly less popular than the other three risk measures combined. This indicates that here we have even stronger evidence than in Panel A that there is no single risk measure that is preferred by the majority of investors to all other risk measures. It should be kept in mind that all the alternatives have the same expected return. The answers to Question 5 in Panel B indicate that $54.85 \%$ of the respondents, who are concerned with either the probability of a loss or the expected value of a loss, are more concerned about the underperformance relative to the market return than relative to the initial investment or 
the risk-free rate of return. Question 6 looks at the same respondents, but asks whether they are more concerned about underperformance with regard to the market or the riskfree rate combined (Answer 1) or with regard to the initial investment (Answer 2). In Panel B we find that $41.87 \%$ is more concerned about underperformance with regard to the market or the risk-free rate than with regard to a return of zero. Questions 7 and 8 are for the respondents who indicated earlier that they find the semi-variance to be the most important risk measure. On both Questions 7 and 8 their responses are almost equally divided between Answers 1 and 2.

We can now set up Figure II which is similar to Figure I, except that we now look at the total investment instead of the marginal investment.

[Please insert Figure II here]

The first conclusion that can be drawn from Figure II is that the variance is an even less common choice as a risk measure for the total investment than it is for the marginal investment. The number of respondents choosing for variance as the risk measure decreases from $42.09 \%$ in Figure I to $33.33 \%$ in Figure II. Moreover we see that no less than $81.48 \%$ of the respondents that choose variance as a risk measure, have chosen for at least one asymmetric risk measure. This means that only 20 out of 324 respondents $(6 \%)$ systematically choose variance as the only risk measure. When we look at the choice of the asymmetric risk measures, we see similar results with a smaller popularity of the semi-variance than in Figure I. Given the difference in results between Panel A and Panel B in Table III this result is not surprising. Furthermore we can see that the expected value of loss has become more popular as a risk measure for those respondents that did choose variance in Question 4. It is not surprising that investors 
become more concerned about the expected value of a loss when an investment of 20,000 euro is considered instead of an investment of 1,000 euro.

In line with Figures I and II we investigate how many respondents systematically choose one risk measure. With "systematically choosing" we mean selecting an alternative that minimizes this risk measure in all four questions. In Figure I we find that 28 out of 449 respondents systematically choose the variance as the most important risk measure. We also investigate this for the other risk measures. The results of this analysis are presented in Table IV.

\section{[Please insert Table IV here]}

Panel A presents the results for the marginal investment. We find that in total 155 respondents systematically choose one risk measure: 31 investors go for probability of loss, 74 investors for semi-variance, 22 for expected value of loss, and the earlier reported 28 for variance. If we express this as a percentage, we find that $47.74 \%$ of the investors, which systematically choose one risk measure, choose semi-variance as that risk measure. The $\chi^{2}$ test, which tests for the non-randomness of the distribution of answers, is significant at the $1 \%$-level. From Figure I we conclude that approximately $6 \%$ of the investors systematically choose the variance as a risk measure. Table IV shows that more than $16 \%$ systematically chooses for the semi-variance. The results for the total investment are not dramatically different. In this case $41.04 \%$ of those investors who systematically choose the same risk measure choose the semi-variance. This can be compared to $14.93 \%$ for the variance, $26.12 \%$ for the probability of loss, and $17.91 \%$ for the expected value of loss. Thus, we find that all four risk measures play a role in investment decisions. However, the semi-variance, which is a special case of the $\alpha-\mathrm{t}$ 
model $(\alpha=2)$ is by far the most important risk measure. The other three risk measures, which include the variance (a symmetric risk measure), and the two other special cases of the $\alpha$-t model, the expected value of loss $(\alpha=1)$ and the probability of loss $(\alpha=0)$, are less important risk measures.

Table V shows how the individuals' answers to Questions 1 to 8 for the amounts of 1,000 are related to their answers to the same questions for the amount of 20,000 euro.

[Please insert Table V here]

Separately for every question we report Pearson's $\chi^{2}$ statistics and Phi coefficients. Pearson's $\chi^{2}$ statistics is used to test the null hypothesis that the responses to each pair of questions are independent. For all four risk measure questions the null hypothesis is rejected at the $1 \%$-level, suggesting that people tend to make the same choice, irrelevant of the amount of money at stake. A similar result holds for the benchmark questions, although the significance levels for these questions vary from 1 to 10 percent. In order to assess how closely the answers between the small- and large-amount questions are related, we also calculate Phi coefficients, calculated as $\sqrt{\chi^{2} / N}$, where $N$ is the number of observations. Similarly to the correlation coefficient, Phi coefficients measure the association between two groups of responses, but are robust to nonlinearity. They can vary from 0 to 1 , with a high number indicating a stronger relation between the two series. The values of the Phi coefficients, reported in Table V, suggest a strong association between the two series. This is especially the case for the risk measure questions, where they all lie between 0.4 and 0.5 . Respondents tend to vary their answers slightly more with regard to the benchmark, especially those who selected probability and expected value of loss as their main risk concern. 


\section{Benchmarks}

In addition to the experimental questions on the benchmark, we also explicitly ask respondents how they evaluate the performance of their stocks. We only ask this question to respondents with investments in stocks and/or investment funds. These results are included in Table VI.

\section{[Please insert Table VI here]}

From Table VI it can be concluded that most investors consider the initial investment to be the most important benchmark (58.95\%). This is followed by the riskfree rate of return $(28.09 \%)$ and the stock market return $(7.13 \%)$. The finding that investors strongly rely on the initial value is also documented in the behavioral finance literature. De Bondt [1998] argues that, next to the market return, the original purchase price is a "highly salient reference point". He argues (page 837): "How many people can bring themselves to sell off a house at a price that is lower than what they paid for it?" The reliance on the initial value is also an important element of the disposition effect, first documented by Shefrin and Statman [1985]. This is the effect that investors are reluctant to sell assets trading at a loss relative to the price at which they were purchased.

The investors' benchmarks can also be derived from our experimental questions. This analysis is presented in Table VII.

\section{[Please insert Table VII here]}

The results in Table VII are again only for investors. This table only includes those respondents who indicated a preference for one or more of the asymmetric risk 
measures in Questions 1-4. Based on the answers to Questions 5-8 it is possible to derive which benchmark investors implicitly choose. From this table it can be concluded that the market return is the most important benchmark for all investors $(39.66 \%)$, followed by the zero return $(28.65 \%)$ and the risk-free rate of return $(17.65 \%)$. The market return is an even more important benchmark for the investors who choose the semi-variance of returns. The subjects who implicitly choose one of the other asymmetric risk measures find the initial investment to be the most important benchmark. Finally, it is possible that respondents give inconsistent results. For example, the choice of Answer 1 on Question 5 would imply that the respondent finds the market return a more important benchmark than either the risk-free rate of return or zero. If the same respondent would Answer 2 to Question 6 it would mean that this respondent finds a zero return to be a more important benchmark than either the market return or the risk-free rate of return. This sequence of choices is obviously inconsistent. Similarly, it is inconsistent to Answer 1 to Question 7 followed by 2 on Question 8. If all the respondents would have filled out the questionnaire randomly, this would have been the case for an expected $25 \%$ of the respondents. In reality $14.04 \%$ of the respondents showed this inconsistency. This number is different from the earlier mentioned $25 \%$ on the $1 \%$-significance level. It should be noticed that inconsistencies are common in the literature on experimental economics and experimental finance. For example, Loomes, Starmer, and Sugden [1991] find that a large number of subjects prefer a $60 \%$ chance of $£ 8$ over a $30 \%$ chance of $£$ 18. The same subjects also prefer a certain amount of $£ 4$ over a $60 \%$ chance of $£ 8$ and they prefer a $30 \%$ chance of $£ 18$ over a certain $£ 4$. This clear violation of the transitivity rule accounted for approximately 17 percent of the patterns resulting from pairwise 
choices in their study. The questions and the choices in our study are very complicated. For this reason it is highly unlikely that any of the respondents was aware of the fact that they gave inconsistent answers. Furthermore, the respondents were not informed in any way that they could give inconsistent answers. In this context it is not surprising that a relatively large number of respondents gave inconsistent answers.

The results for the total investment show some interesting differences compared to the results for the marginal investment. First we see that the number of inconsistent responses goes up to $20.95 \%$. This result is still significantly different at the $5 \%$-level from the $25 \%$-score that would have resulted if the questionnaire were filled out randomly. We also see that the risk-free rate of return is still not very popular as a benchmark $(13.79 \%$ compared to $17.65 \%$ for the marginal investment). However, we now see that the initial investment is more popular as a benchmark than the market return (33.42\% versus $31.83 \%$ ). Apparently, as the stakes get higher, investors focus more on the initial investment than on the market return, or put in terms of popular investment books, "greed" is overcome by "fear".

Reviewing the results for both the marginal and the total investments it can be concluded that there is still a large divergence between the respondents' answers to a direct question with regard to their benchmarks and their implicit choices. Table VI shows an overwhelming preference for the initial investment (58.95\%) over the market return $(7.13 \%)$ as an anchor. However, looking at Table VII we find that there is a marginal support for the initial investment as an anchor when we look at the total investment (33.42\% versus 31.83\%). When looking at the marginal investments, we even see a reversal, in the sense that the market return is more popular than the zero return. 


\section{Effect of background data}

We also test whether the answers to the experimental questions are related to respondents' demographics. We distinguish the following demographic categories: age (below 55 versus 55 and older), gender, education (university or college versus other), and monthly gross income (below 2,000 euro versus above 2,000 euro). We do not find any systematic relationship revealed preferences for a particular risk measure (by answering "1" or "2" on Questions 1-4) and demographics. For this reason we do not present these results here. ${ }^{22}$ However, we do find interesting differences in the frequency of answering " 3 " ("indifferent") and " 4 " ("question is not clear") for different demographic groups. It should be noted that the answer "question is not clear" may both refer to not understanding the question or to not caring about it. Based on the answers to Questions 1 to 4 we construct a variable that is equal to 1 when the respondents replied either "3" or " 4 " to at least one of the Questions 1 to 4 of the survey and 0 otherwise. This variable is the dependent variable in a logit model, the results of which are presented in Table VIII. Note that Questions 5 to 8 are left out because respondents only received these questions if they answered Alternative 1 to Question 1,2, or 3. Since the results are virtually the same for the two experimental questionnaire studies, we only present the results for the first experimental questionnaire study. ${ }^{23}$

[Please Insert Table VIII here]

\footnotetext{
${ }^{22}$ These results are, on request, available from the authors.

${ }^{23}$ The results for the second experiment are, on request, available from the authors.
} 
Panel A of Table VIII presents the results for all the respondents. Here we see interesting differences within most demographic categories. More specifically, we see that younger investors are more likely to make a firm choice (Alternative 1 or 2) than older investors. Similarly, female respondents are more likely to answer "3" or " 4 " than male respondents. This is line with the results of Barber and Odean [2001] who find that men are more overconfident than women. Our results do not say that men are overconfident, but they do indicate that men are more confident than women in making a choice between two investments. In addition we find that higher earning respondents are more likely to make firm choices than lower earnings respondents. Panel B of Table VIII presents the results for the investors. Here we see that the difference between demographic categories slightly change. As far as age is concerned, the significance level decreases from $1 \%$ to $10 \%$. The reverse change applies to gender. The significance of the income effect disappears.

In Table IX we test whether a preference for a particular risk measure can explain in which risky assets people tend to invest.

\section{[Please insert Table IX here]}

This is tested by estimating a logit model, where the dependent variable is equal to 1 when the respondent has invested money in a particular risky asset, and 0 otherwise. Based on our finding in Table VIII that not being able to choose between alternatives is driven by background, we also include demographic variables. The analysis in Table IX is only carried out for the most common investment categories: stocks, investment funds, and corporate bonds. ${ }^{24} \mathrm{~A}$ comparison of stock and bond investments is interesting for our

\footnotetext{
${ }^{24}$ There is, of course, a possibility that the decisions to invest in separate asset categories are correlated. For this reason we also ran bivariate probit regressions for different asset categories (exchange-traded
} 
purposes, since these two categories not only have a different amount of risk associated with them, but also differ in their risk profile. We use the preferences for the particular risk measure, derived from the answers to the Experimental Questions 1 to 4, as explanatory variables in the regressions. ${ }^{25} \mathrm{We}$ find that respondents with a preference for the semi-variance as a risk measure are more likely to hold individual stocks. This is the only risk measure in this category that is significantly different from zero (on the 1\%level). The only significant risk measure for corporate bond investors is the probability of a loss. It is in line with intuition that bond investors have different preferences than stock investors. Bond investors are a priori expected to be more concerned about the probability of losing part of their initial investment compared to stock investors, since they invest in an instrument that limits this probability. We find that investors in investment funds have a preference for two risk measures, i.e. the semi-variance, and the probability of a loss. This could be expected because investment funds may combine both equity and fixed income assets. Consequently, these investors share the preferences of both stock and bond investors. Overall, results of these regressions show that the different types of risk attitudes among individual investors, found in the previous parts of the paper, directly translate into their investment behavior. Individuals tend to choose their investments into risky assets according to their risk perceptions and the risk profile of the different assets, thereby displaying a clear clientele effect.

stocks, corporate bonds, and investment funds). These regressions show high correlations between holdings of the different financial instruments, varying from 0.36 for corporate bonds and investment funds to 0.39 between exchange-traded stocks and corporate bonds and 0.46 for exchange-traded stocks and investment funds. However, for the rest the bivariate probits show very much the same results as the univariate probits. Exact results are available from the authors.

${ }^{25}$ Following the advice of one of the referees, we have also looked at interaction effects between different risk measures. These effects are generally nonsignificant, and the results for the stocks and investment funds remain unchanged. However, for bondholders, adding interaction variables makes probability of loss nonsignificant and the variance becomes significant. The exact results are, on request, available from the authors. 


\section{Summary and conclusions}

Finance and investment textbooks generally consider the variance of portfolio returns to be the most important risk measure, used in the risk-return trade-off. On the other hand, in the common perception risk is mostly related to the possibility and magnitude of negative deviations from the benchmark. This definition is supported by Fishburn [1977] and is recognized by most of the financial institutions that construct risk profiles of their clients. Many of their questionnaires contain questions that measure risk tolerance both by the variance of returns and by shortfall measures. The purpose of this paper is to test which risk measures influence the individual investors' decision making. We find that investors implicitly use a variety of risk measures at the same time. The variance is one of these risk measures, but besides the variance, investors also use several measures of shortfall risk. In particular, semi-variance of returns is found to reflect the investors' risk perceptions most often. This risk measure combines the quadratic nature of variance with the common notion of risk as a negative phenomenon. Even stronger, we find that investors' real-life choices of risky investments are directly influenced by their risk perceptions revealed in the experimental questionnaire study. The results of our study can be potentially useful for the financial institutions in finding out which risks are most important for their clients.

Another area where the results of this study can be useful is on the topic of benchmarking. We find an interesting discrepancy between investor responses and the results of an experimental questionnaire study on risk measures. In general individual investors claim that they find the initial investment to be the most important benchmark. 
However, the experimental questionnaire study shows that for a large amount $(€ 20,000)$ the market return and the initial investment are virtually equally popular benchmarks. For a small investment $(€ 1,000)$ the market return is considered to be the most important benchmark. In either case, the investors seem to make different choices from their stated preferences. 


\section{References}

Barber, M., and Odean, T., 2001, "Boys will be boys: gender, overconfidence, and common stock investment", The Quarterly Journal of Economics 116, 261-292.

Barberis, N., 2000, "Investing for the long run when returns are predictable", The Journal of Finance 55, 225-264.

Barberis, N., and Huang, M., 2001, "Mental accounting, loss aversion, and individual stock returns", The Journal of Finance 56, 1247-1292.

Bellemare, C., Krause, M., Kröger, S., and Zhang, C., 2005, "Myopic loss aversion: information feedback vs. investment flexibility", Economics Letters 87, 319-324.

Berkelaar, A.B., Kouwenberg, R., and Post, T., 2004, “Optimal portfolio choice under loss aversion", The Review of Economics and Statistics 86, 973-987.

Bertsimas, D., Lauprete, G.J., and Samarov, A., 2004, "Shortfall as a risk measure: properties, optimization and applications", Journal of Economic Dynamics \& Control 28, 1353-1381.

Bodie, Z., 1991, "Shortfall risk and pension fund management", Financial Analysts Journal 47, May-June, 57-61.

Bodie, Z., Kane, A., and Marcus, A.J., 2002. Investments, 5th edition, McGrawHill/Irwin, New York.

Camerer, C., 1995, "Individual decision making”, in: Kagel, J.H., and Roth, A.E. (eds.), The Handbook of Experimental Economics, Princeton University Press, 587-703. 
De Bondt, W.F.M., 1998, “A portrait of the individual investor”, European Economic Review 42, 831-844.

Dong, M., Robinson, C., and Veld, C., 2005, "Why individual investors want dividends", Journal of Corporate Finance 12, 121-158.

Fishburn, P.C., 1977, "Mean-risk analysis with risk associated with below-target returns", The American Economic Review 67, 116-126.

Gneezy, U., and Potters, J., 1997, “An experiment on risk taking and evaluation periods”, The Quarterly Journal of Economics 112, 631-646.

Gneezy, U., Kapteyn, A., and Potters, J., 2003, "Evaluation periods and asset prices in a market experiment", The Journal of Finance 58, 821-838.

Guiso, L., Sapienza, P., and Zingales, L., 2007, “Trusting the stock market”, Working paper, University of Sassari, University of Chicago, Northwestern University, Harvard University, NBER, and CEPR, January.

Haigh, M.S., and List, J.A., 2005, "Do professional traders exhibit myopic loss aversion? An experimental analysis", The Journal of Finance 60, 523-534.

Harless, D.W., and Camerer, C.F., 1994, "The predictive utility of generalized expected utility theories", Econometrica 62, 1251-1289.

Hey, J.D., and Orme, C., 1994, "Investigating generalizations of expected utility theory using experimental data", Econometrica 62, 1291-1326.

Holt, C.A., and Laury, S.K., 2002, "Risk aversion and incentive effects", The American Economic Review 92, 1644-1655. 
Kahneman, D., Knetsch, J.L., and Thaler, R.H., 1990, "Experimental tests of the endowment effect and the Coase theorem", The Journal of Political Economy 98, $1325-1348$.

Kahneman, D., and Tversky, A., 1979, "Prospect theory: an analysis of decision under risk", Econometrica 47, 263-292.

Leibowitz, M.L., and Kogelman, S., 1991, “Asset allocation under shortfall constraints”, The Journal of Portfolio Management 17, Winter, 18-23.

Loomes, G., Starmer, C., and Sugden, R., 1991, “Observing violations of transitivity by experimental methods", Econometrica 59, 425-439.

Markowitz, H., 1959, “Portfolio Selection”, Wiley, New York.

Merton, R., 1969, "Lifetime portfolio selection: the continuous-time case", Review of Economics and Statistics 51, 247-257.

Milevsky, M.A., Ho, K., and Robinson, C., 1997, “Asset allocation with the conditional first exit time or How to avoid outliving your money", Review of Quantitative Finance and Accounting 9, 53-70.

Rabin, M., 2000, "Risk aversion and expected-utility theory: a calibration theorem", Econometrica 68, 1281-1292.

Ross, S.A, Westerfield, R.W., and Jaffe, J.F., 2005. Corporate Finance, 7th edition, McGraw-Hill, New York.

Roy, A.D., 1952, "Safety first and the holding of assets", Econometrica 20, 431-439. 
Shefrin, H., and Statman, M., 1985, “The disposition to sell winners too early and ride losers too long: theory and evidence", The Journal of Finance 40, 777-792.

Samuelson, P., 1970, "The fundamental approximation theorem of portfolio analysis in terms of means, variances, and higher moments", Review of Economic Studies 27, $1970,537-542$.

Thaler, R.H., Tversky, A., Kahneman, D., and Schwartz, A., 1997, “The effect of myopia and loss aversion on risk taking: an experimental test", The Quarterly Journal of Economics 106, 1039-1061.

Tversky, A., and Kahneman, D., 1974, "Judgement under uncertainty: heuristics and biases", Science 185, 1124-1130.

Tversky, A., and Kahneman, D., 1992, "Advances in prospect theory: cumulative representation of uncertainty", The Journal of Risk and Uncertainty 5, 297-323.

Unser, M., 2000, “Lower partial moments as measures of perceived risk: an experimental study", Journal of Economic Psychology 21, 253-280. 


\section{Table I. Explanation of Questions 1 to 8}

Questions 1 to 8 simulate investment opportunities close to those existing on the stock market. All alternatives are calibrated in such a way that their expected return is equal to 10 percent and their standard deviation lies between 14 and 26 percent. Depending on their answers to Questions 1-4, subjects will be presented with the next two pairs of alternatives (Questions 5-8). These questions are meant to find out which of the following three benchmarks are most common when individuals are concerned with downside risk: (1) zero, (2) risk-free rate, (3) market return. Questions 18 to 25 are identical to Questions 1 to 8, but involve larger monetary amounts $(20,000$ euro instead of 1,000).

\section{Panel A: Questions 1 to 4}

Questions 1 to 4 are designed to determine which measure corresponds most closely to the subjects' perception of risk. While all the alternatives have the same expected return (10 percent), they have the following values of the four risk measures that we study:

\begin{tabular}{|c|c|c|c|c|c|c|}
\hline $\begin{array}{l}\text { Question, } \\
\text { alternative }\end{array}$ & Description of alternative & $\begin{array}{l}\text { Standard } \\
\text { deviation } \\
(\%)\end{array}$ & $\begin{array}{l}\text { Probability } \\
\text { of loss }(\%)\end{array}$ & $\begin{array}{l}\text { Expected } \\
\text { value of } \\
\text { loss }\end{array}$ & $\begin{array}{l}\text { Semi- } \\
\text { variance } \\
(\%)\end{array}$ & Expected outcome \\
\hline 1,1 & $\begin{array}{l}10 \% \text { chance of } € 200 \text {, and } 90 \% \text { chance of } \\
€ 1,200\end{array}$ & 30.0 & 10 & -80 & 640 & \multirow{2}{*}{$\begin{array}{l}\text { (1) will be chosen if the } \\
\text { subjects are mostly concerned } \\
\text { about probability of loss }\end{array}$} \\
\hline 1,2 & $\begin{array}{l}40 \% \text { chance of } € 920 \text {, and } 60 \% \text { chance of } \\
€ 1,220\end{array}$ & 14.7 & 40 & -32 & 25.6 & \\
\hline 2,1 & $\begin{array}{l}70 \% \text { chance of } € 930 \text {, and } 30 \% \text { chance of } \\
€ 1,500\end{array}$ & 26.1 & 70 & -49 & 34.3 & $\begin{array}{l}\text { (1) will be chosen if the } \\
\text { subjects are mostly concerned } \\
\text { about semi-variance }\end{array}$ \\
\hline 3,1 & $\begin{array}{l}10 \% \text { chance of } € 640,60 \% \text { chance of } € 990 \text {, } \\
\text { and } 30 \% \text { chance of } € 1,470\end{array}$ & 26.4 & 70 & -42 & 130.2 & \multirow{2}{*}{$\begin{array}{l}\text { (1) will be chosen if the } \\
\text { subjects are mostly concerned } \\
\text { about expected value of loss }\end{array}$} \\
\hline 3,2 & $\begin{array}{l}15 \% \text { chance of } € 800,40 \% \text { chance of } € 920 \text {, } \\
\text { and } 45 \% \text { chance of } € 1,360\end{array}$ & 23.9 & 55 & -62 & 85.6 & \\
\hline 4,1 & $\begin{array}{l}25 \% \text { chance of } € 800 \text {, and } 75 \% \text { chance of } \\
€ 1,200\end{array}$ & 17.3 & 25 & -50 & 100 & $\begin{array}{l}\text { (1) will be chosen if the } \\
\text { subjects are mostly concerned } \\
\text { about total variance }\end{array}$ \\
\hline
\end{tabular}




\section{Panel B: Questions 5 and 6}

Questions 5 and 6 are presented to subjects who chose "1" as an answer to Questions 1 and/or 3. Alternatives 1 and 2 in these questions have the same expected value and standard deviation, but are associated with the following downside risk measures:

\begin{tabular}{|c|c|c|c|c|c|c|c|c|}
\hline \multirow[t]{2}{*}{$\begin{array}{l}\text { Question, } \\
\text { alternative }\end{array}$} & \multirow[t]{2}{*}{ Description of alternative } & \multicolumn{2}{|c|}{ Target $=$ zero } & \multicolumn{2}{|c|}{$\begin{array}{c}\text { Target }=\text { risk-free rate } \\
\qquad(4 \%)\end{array}$} & \multicolumn{2}{|c|}{$\begin{array}{c}\text { Target }=\text { market return } \\
(10 \%)\end{array}$} & \multirow[t]{2}{*}{ Expected outcome } \\
\hline & & $\begin{array}{l}\text { Probability } \\
\text { of loss }(\%)\end{array}$ & $\begin{array}{l}\text { Expected } \\
\text { value of } \\
\text { loss }\end{array}$ & $\begin{array}{l}\text { Probability } \\
\text { of loss (\%) }\end{array}$ & $\begin{array}{l}\text { Expected } \\
\text { value of } \\
\text { loss }\end{array}$ & $\begin{array}{l}\text { Probability } \\
\text { of loss }(\%)\end{array}$ & $\begin{array}{l}\text { Expected } \\
\text { value of } \\
\text { loss }\end{array}$ & \\
\hline 5,1 & $\begin{array}{l}10 \% \text { chance of } € 680,5 \% \\
\text { chance of } € 1,050, \text { and } 85 \% \\
\text { chance of } € 1,150\end{array}$ & 10 & -32 & 10 & -36 & 15 & -44 & $\begin{array}{l}\text { (1) will be chosen if the subjects } \\
\text { are mostly concerned about } \\
\text { probability/expected value of }\end{array}$ \\
\hline 5,2 & $\begin{array}{l}5 \% \text { chance of } € 730,70 \% \\
\text { chance of } € 1,050 \text {, and } 25 \% \\
\text { chance of } € 1,310\end{array}$ & 5 & -14 & 5 & -16 & 75 & -53 & $\begin{array}{l}\text { underperforming relative to the } \\
\text { market }\end{array}$ \\
\hline 6,1 & $\begin{array}{l}10 \% \text { chance of } € 800,50 \% \\
\text { chance of } € 1,030, \text { and } 40 \% \\
\text { chance of } € 1,260\end{array}$ & 10 & -20 & 60 & -29 & 60 & -64 & $\begin{array}{l}\text { (2) will be chosen if the subjects } \\
\text { are mostly concerned about } \\
\text { probability /expected value of }\end{array}$ \\
\hline 6,2 & $\begin{array}{l}5 \% \text { chance of } € 900,60 \% \\
\text { chance of } € 1,000 \text {, and } 35 \% \\
\text { chance of } € 1,300\end{array}$ & 5 & -5 & 65 & -31 & 65 & -70 & $\begin{array}{l}\text { losing part of the initial } \\
\text { investment }\end{array}$ \\
\hline
\end{tabular}

\section{Panel C: Questions 7 and 8}

Questions 7 and 8 are presented to subjects who chose "1" as an answer to Question 2. Alternatives 1 and 2 in these questions have the same expected value of $10 \%$ and standard deviation, but are associated with the following values of semi-variance (in percentage points):

\begin{tabular}{|c|c|c|c|c|c|}
\hline $\begin{array}{l}\text { Question, } \\
\text { alternative }\end{array}$ & Description of alternative & $\begin{array}{l}\text { Target }= \\
\text { zero }\end{array}$ & $\begin{array}{l}\text { Target }= \\
\text { risk-free } \\
\text { rate }(4 \%)\end{array}$ & $\begin{array}{l}\text { Target }= \\
\text { market } \\
\text { return }(10 \%)\end{array}$ & Expected outcome \\
\hline 7,1 & $\begin{array}{l}20 \% \text { chance of } € 940,70 \% \text { chance of } \\
€ 1,070, \text { and } 10 \% \text { chance of } € 1,600\end{array}$ & 7.2 & 20.0 & 57.5 & \multirow{4}{*}{$\begin{array}{l}\text { (1) will be chosen if the subjects are mostly } \\
\text { concerned about the semi-variance of returns } \\
\text { relative to the market } \\
\text { (2) will be chosen if the subjects are mostly } \\
\text { concerned about the semi-variance relative to zero }\end{array}$} \\
\hline 7,2 & $\begin{array}{l}60 \% \text { chance of } € 990,20 \% \text { chance of } \\
€ 1,070, \text { and } 20 \% \text { chance of } € 1,450\end{array}$ & 0.6 & 15.0 & 74.7 & \\
\hline 8,1 & $\begin{array}{l}10 \% \text { chance of } € 900,70 \% \text { chance of } \\
€ 1,030, \text { and } 20 \% \text { chance of } € 1,450\end{array}$ & 10.0 & 20.3 & 74.3 & \\
\hline 8,2 & $\begin{array}{l}50 \% \text { chance of } € 970,20 \% \text { chance of } \\
€ 1,030 \text {, and } 30 \% \text { chance of } € 1,370\end{array}$ & 4.5 & 24.7 & 94.3 & \\
\hline
\end{tabular}




\section{Table II. Investment products.}

This table reports the results of a question in which 2,226 respondents of the CentERpanel were asked which financial products they own or have owned in the past three years. Notes: ${ }^{1}$ A click fund is a fund for which the minimum value at the maturity date is guaranteed. In addition, the underlying value is "clicked" at pre-specified levels. If a value is "clicked" it becomes the new minimum guaranteed payment. ${ }^{2}$ A stock lease plan is the combination of a stock investment and a loan. In this case, the loan is used to finance the stock investment. ${ }^{3}$ Reverse convertibles are bonds that carry high coupon payments, but for which the issuer has the option at the maturity date to either redeem the bonds in cash, or to deliver a prespecified number of shares. ${ }^{4}$ Call and put warrants are bank-issued options. ${ }^{5}$ The investment mortgage is a combination of a mortgage loan and an investment. Individuals pay interest on the mortgage loan, but do not repay the loan until the end of the maturity. Instead they contribute to a life insurance. This contribution is invested for them by the mortgage bank. ${ }^{6}$ In a life annuity the individual pays part of her income to a life insurance company. The insurance company invests the money in stock or in riskless assets. The choice of investment is at the discretion of the investor. The contribution is deducted from income for tax purposes in the year it is paid to the insurance company. At the end of the maturity the individual is obliged to buy a life annuity from the insurance company in order to supplement her pension. The payments for the life annuity are taxable.

\begin{tabular}{|c|c|c|}
\hline Financial product & Number of respondents & Percent \\
\hline 1. Stocks of exchange-listed companies other than investment funds & 285 & 17.50 \\
\hline 2. Stocks of investment funds & 593 & 36.40 \\
\hline 3. Stocks in privately-owned companies & 44 & 2.70 \\
\hline 4. Government bonds & 38 & 2.33 \\
\hline 5. Corporate bonds & 82 & 5.03 \\
\hline 6. Convertible bonds & 19 & 1.17 \\
\hline 7. Savings accounts & 1442 & 88.52 \\
\hline 8. Click funds ${ }^{1}$ & 69 & 4.24 \\
\hline 9. Stock lease plans ${ }^{2}$ & 97 & 5.95 \\
\hline 10. Reverse convertibles ${ }^{3}$ & 6 & 0.37 \\
\hline 11. Call options and warrants ${ }^{4}$ & 54 & 3.31 \\
\hline 12. Put options and warrants ${ }^{4}$ & 26 & 1.60 \\
\hline 13. Investment mortgage ${ }^{5}$ & 196 & 12.03 \\
\hline 14. Life annuity with investment in stocks ${ }^{6}$ & 280 & 17.19 \\
\hline 15. Life annuity without investment in stocks ${ }^{6}$ & 202 & 12.40 \\
\hline 16. Others & 89 & 5.46 \\
\hline Total & 1629 & 100 \\
\hline
\end{tabular}


Table III. Summary of the results for the experimental questions.

Panel A presents the results for the experimental questions (1 to 8) for the marginal investment (an investment of 1,000 euro). Panel B presents the results for the experimental questions ( 1 to 8 ) for the total investment (an investment of 20,000 euro). Columns 2 to 6 show the distribution (in both number of answers and percentage) of all the answers on Questions 1 to 8 . The remaining columns only take into account the respondents who chose Alternatives 1 or 2. They exclude those who answered "3" (Both choices are equally attractive (or unattractive) to me) or "4" (The question is not clear for me). Only answers of individuals who have investments in risky assets (excluding savings accounts and investment mortgages/life annuities) are presented. The numbers in parentheses below the means show values of t-statistics (null hypothesis: mean is equal to 1.5). The numbers in parentheses below the medians show values of Wilcoxon signed ranks test (null hypothesis: median is equal to 1.5). Asterisks indicate significance levels of these tests: ${ }^{*} 10$ percent; ${ }^{* *} 5$ percent; ${ }^{* * *} 1$ percent.

Panel A. Marginal investment.

\begin{tabular}{|c|c|c|c|c|c|c|c|c|c|c|}
\hline \multirow[t]{2}{*}{ Question } & \multicolumn{4}{|c|}{$\begin{array}{c}\text { Number of answers (percentage in } \\
\text { parentheses) }\end{array}$} & \multirow[t]{2}{*}{$\begin{array}{c}\text { Total number of } \\
\text { observations }\end{array}$} & \multicolumn{3}{|c|}{$\begin{array}{l}\text { Number of answers (only } \\
\text { answers } 1 \text { and } 2 \text { count) }\end{array}$} & \multirow[t]{2}{*}{ Mean } & \multirow[t]{2}{*}{ Median } \\
\hline & 1 & 2 & 3 & 4 & & $1(\%)$ & $2(\%)$ & $\begin{array}{c}\text { Total } \\
\text { (number) }\end{array}$ & & \\
\hline (1) & (2) & (3) & (4) & (5) & (6) & (7) & (8) & (9) & (10) & (11) \\
\hline $\begin{array}{l}1:(1=\text { probability of loss } \\
\text { is most important; } \\
2=\text { other risk measures })\end{array}$ & $\begin{array}{c}226 \\
(28.64)\end{array}$ & $\begin{array}{c}393 \\
(49.81)\end{array}$ & $\begin{array}{c}132 \\
(16.73)\end{array}$ & $\begin{array}{c}38 \\
(4.82)\end{array}$ & 789 & 36.51 & 63.49 & 619 & $\begin{array}{l}1.63^{* * *} \\
(6.97)\end{array}$ & $\begin{array}{l}2^{* * *} \\
(6.71)\end{array}$ \\
\hline $\begin{array}{l}2:(1=\text { semi-variance is } \\
\text { most important; } 2=\text { other } \\
\text { risk measures })\end{array}$ & $\begin{array}{c}303 \\
(38.40)\end{array}$ & $\begin{array}{c}302 \\
(38.28)\end{array}$ & $\begin{array}{c}150 \\
(19.01)\end{array}$ & $\begin{array}{c}34 \\
(4.31)\end{array}$ & 789 & 50.08 & 49.92 & 605 & $\begin{array}{c}1.50 \\
(-0.04)\end{array}$ & $\begin{array}{c}1 \\
(0.04)\end{array}$ \\
\hline $\begin{array}{l}3:(1=\text { expected value of } \\
\text { loss is most important; } \\
2=\text { other risk measures })\end{array}$ & $\begin{array}{c}162 \\
(20.53)\end{array}$ & $\begin{array}{c}363 \\
(46.01)\end{array}$ & $\begin{array}{c}226 \\
(28.64)\end{array}$ & $\begin{array}{c}38 \\
(4.82)\end{array}$ & 789 & 30.86 & 69.14 & 525 & $\begin{array}{l}1.69^{* * *} \\
(9.49)\end{array}$ & $\begin{array}{l}2^{* * *} \\
(8.77)\end{array}$ \\
\hline $\begin{array}{l}\text { 4: }(1=\text { variance is most } \\
\text { important; } 2=\text { other risk } \\
\text { measures })\end{array}$ & $\begin{array}{c}243 \\
(30.80)\end{array}$ & $\begin{array}{c}391 \\
(49.56)\end{array}$ & $\begin{array}{c}123 \\
(15.59)\end{array}$ & $\begin{array}{c}32 \\
(4.06)\end{array}$ & 789 & 38.33 & 61.67 & 634 & $\begin{array}{l}1.62^{* * *} \\
(6.04)\end{array}$ & $\begin{array}{c}2^{* * *} \\
(5.88)\end{array}$ \\
\hline $\begin{array}{l}\text { 5: Benchmark } \\
(1=\text { market; } 2=\text { risk-free } \\
\text { rate or zero })\end{array}$ & $\begin{array}{c}147 \\
(45.65)\end{array}$ & $\begin{array}{c}158 \\
(49.07)\end{array}$ & $\begin{array}{c}16 \\
(4.97)\end{array}$ & $\begin{array}{c}1 \\
(0.31)\end{array}$ & 322 & 48.20 & 51.80 & 305 & $\begin{array}{c}1.52 \\
(0.63)\end{array}$ & $\begin{array}{c}2 \\
(0.63)\end{array}$ \\
\hline $\begin{array}{l}6: \text { Benchmark } \\
(1=\text { market or risk-free } \\
\text { rate; } 2=\text { zero })\end{array}$ & $\begin{array}{c}141 \\
(43.79)\end{array}$ & $\begin{array}{c}134 \\
(41.61)\end{array}$ & $\begin{array}{c}45 \\
(13.98)\end{array}$ & $\begin{array}{c}2 \\
(0.62)\end{array}$ & 322 & 51.27 & 48.73 & 275 & $\begin{array}{c}1.49 \\
(-0.42)\end{array}$ & $\begin{array}{c}1 \\
(0.42)\end{array}$ \\
\hline $\begin{array}{l}\text { 7: Benchmark } \\
(1=\text { market; } 2=\text { risk-free } \\
\text { rate or zero) }\end{array}$ & $\begin{array}{c}168 \\
(55.45)\end{array}$ & $\begin{array}{c}110 \\
(36.30)\end{array}$ & $\begin{array}{c}22 \\
(7.26)\end{array}$ & $\begin{array}{c}3 \\
(0.99)\end{array}$ & 303 & 60.43 & 39.57 & 278 & $\begin{array}{l}1.40^{* * *} \\
(-3.55)\end{array}$ & $\begin{array}{c}1^{* * *} \\
(3.48)\end{array}$ \\
\hline $\begin{array}{l}8: \text { Benchmark } \\
(1=\text { market or risk-free } \\
\text { rate; } 2=\text { zero })\end{array}$ & $\begin{array}{c}174 \\
(57.43)\end{array}$ & $\begin{array}{c}99 \\
(32.67)\end{array}$ & $\begin{array}{c}26 \\
(8.58)\end{array}$ & $\begin{array}{c}4 \\
(1.32)\end{array}$ & 303 & 63.74 & 36.26 & 273 & $\begin{array}{l}1.36^{* * *} \\
(-4.71)\end{array}$ & $\begin{array}{c}1^{* * *} \\
(4.54)\end{array}$ \\
\hline
\end{tabular}


Panel B. Total investment.

\begin{tabular}{|c|c|c|c|c|c|c|c|c|c|c|}
\hline \multirow[t]{2}{*}{ Question } & \multicolumn{4}{|c|}{$\begin{array}{c}\text { Number of answers (percentage in the } \\
\text { parentheses) }\end{array}$} & \multirow{2}{*}{$\begin{array}{l}\text { Total number } \\
\text { of } \\
\text { observations } \\
\end{array}$} & \multicolumn{3}{|c|}{$\begin{array}{l}\text { Number of answers (only answers } \\
1 \text { and } 2 \text { count) }\end{array}$} & \multirow[t]{2}{*}{ Mean } & \multirow[t]{2}{*}{ Median } \\
\hline & 1 & 2 & 3 & 4 & & $1(\%)$ & $2(\%)$ & $\begin{array}{c}\text { Total } \\
\text { (number) }\end{array}$ & & \\
\hline (1) & (2) & (3) & (4) & (5) & (6) & (7) & (8) & (9) & (10) & (11) \\
\hline $\begin{array}{l}\text { 1: }(1=\text { probability of loss } \\
\text { is most important; } \\
2=\text { other risk measures })\end{array}$ & $\begin{array}{c}177 \\
(26.90)\end{array}$ & $\begin{array}{c}314 \\
(47.72)\end{array}$ & $\begin{array}{c}148 \\
(22.49)\end{array}$ & $\begin{array}{c}19 \\
(2.89)\end{array}$ & 658 & 36.05 & 63.95 & 491 & $\begin{array}{l}1.64^{* * *} \\
(6.43)\end{array}$ & $\begin{array}{l}2^{* * *} \\
(6.18)\end{array}$ \\
\hline $\begin{array}{l}2:(1=\text { semi-variance is } \\
\text { most important; } 2=\text { other } \\
\text { risk measures })\end{array}$ & $\begin{array}{c}200 \\
(30.40)\end{array}$ & $\begin{array}{c}267 \\
(40.58)\end{array}$ & $\begin{array}{c}172 \\
(26.14)\end{array}$ & $\begin{array}{c}19 \\
(2.89)\end{array}$ & 658 & 42.83 & 57.17 & 467 & $\begin{array}{l}1.57^{* * *} \\
(3.13)\end{array}$ & $\begin{array}{l}2^{* * *} \\
(3.10)\end{array}$ \\
\hline $\begin{array}{l}3:(1=\text { expected value of } \\
\text { loss is most important; } \\
2=\text { other risk measures })\end{array}$ & $\begin{array}{c}129 \\
(19.60)\end{array}$ & $\begin{array}{c}242 \\
(36.78)\end{array}$ & $\begin{array}{c}266 \\
(40.43)\end{array}$ & $\begin{array}{c}21 \\
(3.19)\end{array}$ & 658 & 34.77 & 65.23 & 371 & $\begin{array}{l}1.65^{* * *} \\
(6.15)\end{array}$ & $\begin{array}{c}2^{* * *} \\
(5.87)\end{array}$ \\
\hline $\begin{array}{l}\text { 4: }(1=\text { variance is most } \\
\text { important; } 2=\text { other risk } \\
\text { measures })\end{array}$ & $\begin{array}{c}147 \\
(22.34)\end{array}$ & $\begin{array}{c}344 \\
(52.28)\end{array}$ & $\begin{array}{c}146 \\
(22.19)\end{array}$ & $\begin{array}{c}21 \\
(3.19)\end{array}$ & 658 & 29.94 & 70.06 & 491 & $\begin{array}{l}1.70^{* * *} \\
(9.70)\end{array}$ & $\begin{array}{c}2^{* * *} \\
(8.89)\end{array}$ \\
\hline $\begin{array}{l}\text { 5: Benchmark } \\
(1=\text { market; } 2=\text { risk-free } \\
\text { rate or zero) }\end{array}$ & $\begin{array}{c}130 \\
(49.62)\end{array}$ & $\begin{array}{c}107 \\
(40.84)\end{array}$ & $\begin{array}{c}23 \\
(8.78)\end{array}$ & $\begin{array}{c}2 \\
(0.76)\end{array}$ & 262 & 54.85 & 45.15 & 237 & $\begin{array}{c}1.45 \\
(-1.50)\end{array}$ & $\begin{array}{c}1 \\
(1.49)\end{array}$ \\
\hline $\begin{array}{l}6: \text { Benchmark } \\
(1=\text { market or risk-free } \\
\text { rate; } 2=\text { zero })\end{array}$ & $\begin{array}{c}89 \\
(33.97)\end{array}$ & $\begin{array}{c}124 \\
(47.33)\end{array}$ & $\begin{array}{c}47 \\
(17.94)\end{array}$ & $\begin{array}{c}2 \\
(0.76)\end{array}$ & 262 & 41.87 & 58.22 & 213 & $\begin{array}{l}1.58^{* *} \\
(2.43)\end{array}$ & $\begin{array}{c}2^{* *} \\
(2.40)\end{array}$ \\
\hline $\begin{array}{l}7: \text { Benchmark } \\
(1=\text { market; } 2=\text { risk-free } \\
\text { rate or zero })\end{array}$ & $\begin{array}{c}92 \\
(46.00)\end{array}$ & $\begin{array}{c}90 \\
(45.00)\end{array}$ & $\begin{array}{c}17 \\
(8.50)\end{array}$ & $\begin{array}{c}1 \\
(0.50)\end{array}$ & 200 & 50.55 & 49.45 & 182 & $\begin{array}{c}1.49 \\
(-0.15)\end{array}$ & $\begin{array}{c}1 \\
(0.15)\end{array}$ \\
\hline $\begin{array}{l}8: \text { Benchmark } \\
(1=\text { market or risk-free } \\
\text { rate; } 2=\text { zero })\end{array}$ & $\begin{array}{c}88 \\
(44.00)\end{array}$ & $\begin{array}{c}89 \\
(44.50)\end{array}$ & $\begin{array}{c}22 \\
(11.00)\end{array}$ & $\begin{array}{c}1 \\
(0.50)\end{array}$ & 200 & 49.72 & 50.28 & 177 & $\begin{array}{c}1.50 \\
(0.07)\end{array}$ & $\begin{array}{c}2 \\
(0.07)\end{array}$ \\
\hline
\end{tabular}




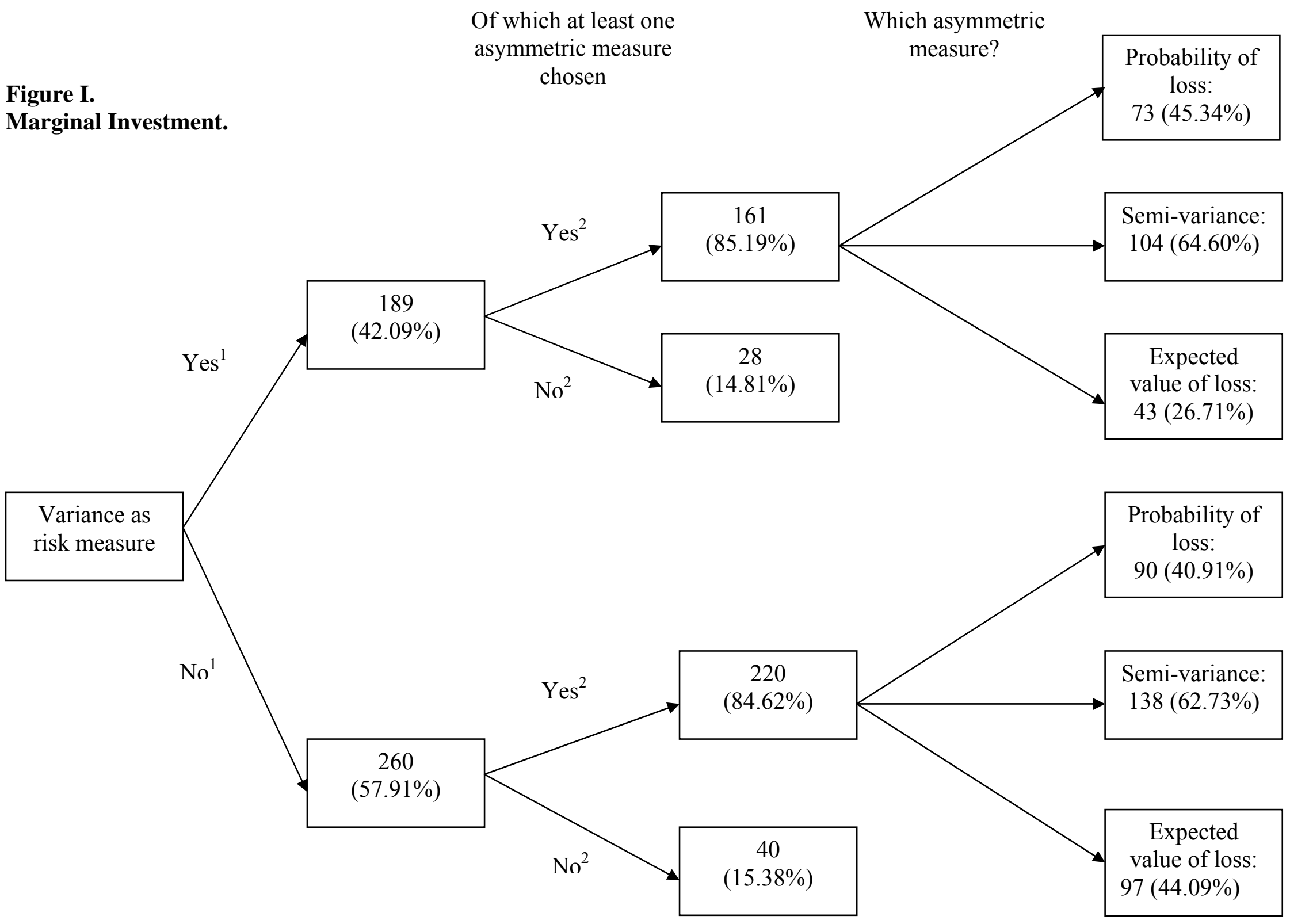

40 
Figure I summarizes the individual choices of the respondents for those who answered "1" or "2" (i.e., gave firm preferences) in all four questions. The total number of observations is equal to 449. The figure starts with the answer to Question 4 in Panel A of Table III and continues from there.

Notes. ${ }^{1}$ The proportion of respondents who chose variance (first node) is significantly different from 0.5 at the $1 \%$-level (the value of the t-test is 3.390; the value of the Wilcoxon test is 3.350$){ }^{2}$ The proportion of respondents who choose at least one asymmetric risk measure is significantly different from 0.5 at the $1 \%$-level. For the 189 respondents who chose variance in the first node, the value of the t-test is equal to 13.580 , the value of the Wilcoxon test is 9.674. For the 260 respondents who did not choose variance in the first node, the value of the t-test is equal to 15.440 , the value of the Wilcoxon test is 11.163 . 
Of which at least one asymmetric measure chosen
Which asymmetric measure?

Figure II.

Total Investment.

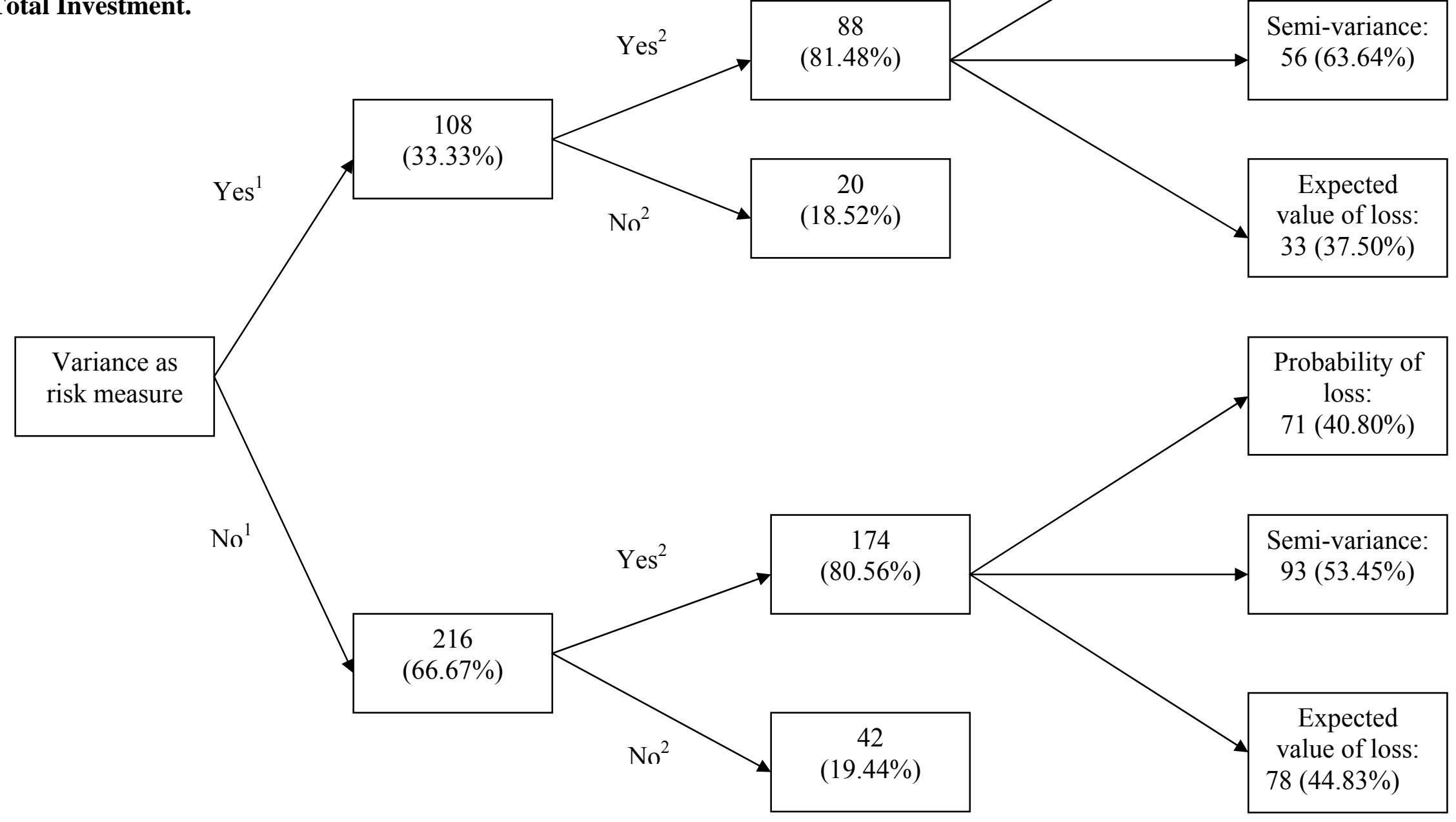


Figure II summarizes the individual choices of the respondents for those who answered "1" or "2" (i.e., gave firm preferences) in all four questions. The total number of observations is equal to 324. The figure starts with the answer to Question 4 in Panel B of Table III and continues from there.

Notes. ${ }^{1}$ The proportion of respondents who chose variance (first node) is significantly different from 0.5 at the $1 \%$-level (the value of the t-test is 6.354; the value of the Wilcoxon test is 6.000). ${ }^{2}$ The proportion of respondents who choose at least one asymmetric risk measure is significantly different from 0.5 at the $1 \%$-level. For the 108 respondents who chose variance in the first node, the value of the t-test is equal to 8.383 , the value of the Wilcoxon test is 6.542 . For the 216 respondents who did not choose variance in the first node, the value of the t-test is equal to 11.320 , the value of the Wilcoxon test is 8.981 . 


\section{Table IV. Consistent choices of risk measure.}

This table presents the risk measures implicitly chosen by the sub-sample of investors who make a consistent choice in Questions 1 to 4. For example, a "consistent choice" of variance implies always choosing the alternative with the least variance, i.e. answering " 1 " in Question 4, and " 2 " in Questions 1 to 3. Panel A presents results for the marginal investment of 1,000 euro. Panel B presents results for an investment of 20,000 euro. The first line in each panel shows the total number of respondents who systematically choose a certain risk measure. The second line is the percentage of the systematic choices that goes to this risk measure. The last row is the percentage of investors who answer "1" or " 2 " (i.e., make a clear decision) on all Questions 1 to 4 , and who systematically choose for a specific risk measure. Investors are defined as those respondents who have investments in risky assets (excluding savings accounts and investment mortgages/life annuities). The last column shows values of the $\chi^{2}$ test for non-randomness of the distribution of the answers. The numbers in the parentheses are the significance levels of the $\chi^{2}$ statistics with 3 degrees of freedom.

\begin{tabular}{|c|c|c|c|c|c|c|}
\hline & $\begin{array}{c}\text { Probability } \\
\text { of loss }\end{array}$ & $\begin{array}{c}\text { Semi- } \\
\text { variance }\end{array}$ & $\begin{array}{c}\text { Expected } \\
\text { value of } \\
\text { loss }\end{array}$ & Variance & Total & $\begin{array}{l}\chi^{2} \text { test } \\
\text { value }\end{array}$ \\
\hline \multicolumn{7}{|c|}{ Panel A. Marginal investment } \\
\hline - number & 31 & 74 & 22 & 28 & 155 & \multirow{3}{*}{$\begin{array}{l}43.84 \\
(p= \\
0.000)\end{array}$} \\
\hline - percent & 20.00 & 47.74 & 14.19 & 18.06 & 100 & \\
\hline $\begin{array}{l}\text { - percent out } \\
\text { of } 449\end{array}$ & 6.90 & 16.48 & 4.90 & 6.24 & 34.52 & \\
\hline \multicolumn{7}{|c|}{ Panel B. Total investment } \\
\hline - number & 35 & 55 & 24 & 20 & 134 & \multirow{3}{*}{$\begin{array}{l}22.00 \\
(p= \\
0.000)\end{array}$} \\
\hline - percent & 26.12 & 41.04 & 17.91 & 14.93 & 100 & \\
\hline $\begin{array}{l}\text { - percent out } \\
\text { of } 324\end{array}$ & 10.80 & 16.98 & 7.41 & 6.17 & 41.36 & \\
\hline
\end{tabular}




\section{Table V. Marginal and total investment.}

This table documents the relationship between individual's answers to Questions 1 to 8 for the amounts of 1,000 and 20,000 euro. Pearson's $\chi^{2}$ statistics is used to test whether the replies to each pair of questions are independent. Phi coefficients measure the association between these responses in a way similar to the correlation coefficient. Phi coefficients can vary from 0 to 1 , with a higher number indicating a stronger relation between the two series. Asterisks indicate significance levels of the Pearson's $\chi^{2}:{ }^{*} 10$ percent; ${ }^{* *} 5$ percent; ${ }^{* * *} 1$ percent.

\begin{tabular}{|c|c|c|c|}
\hline Question & Number of observations & Phi coefficient & Pearson's $\chi^{2}$ \\
\hline \multicolumn{4}{|c|}{ Panel A. Preferred risk measure questions } \\
\hline 1 & 658 & 0.462 & $140.37^{* * *}$ \\
\hline 2 & 658 & 0.458 & $137.72^{* * *}$ \\
\hline 3 & 658 & 0.463 & $141.21^{* * *}$ \\
\hline 4 & 658 & 0.482 & $153.13^{* * *}$ \\
\hline \multicolumn{4}{|c|}{ Panel B. Investors' benchmark questions } \\
\hline 5 & 150 & 0.286 & $12.287^{*}$ \\
\hline 6 & 150 & 0.347 & $18.073^{* * *}$ \\
\hline 7 & 115 & 0.468 & $25.156^{* * *}$ \\
\hline 8 & 115 & 0.412 & $19.519^{* *}$ \\
\hline
\end{tabular}




\section{Table VI. Investors' benchmark.}

Summary of the answers to the question: "When you evaluate the performance of your stock investments (including stocks in investment funds), what is your relevant benchmark?" Only answers of individuals who have investments in risky assets (excluding savings accounts and investment mortgages/life annuities) are presented. The "Probability" column reports one-sided pvalues of the normal approximation for the binomial test (expected proportion of 0.25 ).

\begin{tabular}{llll}
\hline Benchmark & Number of responses & Percent of responses & Probability \\
\hline 1. Initial investment & 405 & 58.95 & 0.000 \\
2. Risk-free rate of return & 193 & 28.09 & 0.031 \\
3. Market return & 49 & 7.13 & 0.000 \\
4. Other & 40 & 5.82 & 0.000 \\
\hline Total & 687 & 100.00 & \\
\hline
\end{tabular}




\section{Table VII. Experimental questions on investors' benchmark.}

This table summarizes the answers of respondents to Questions 5 to 8 of the survey, which measure the benchmark against which investors evaluate the investment alternatives. Only answers of individuals who have investments in risky assets (excluding savings accounts and investment mortgages/life annuities) are presented. Only respondents who indicate a preference for one or more asymmetric risk measures in Questions 1-4 are asked. The initial investment corresponds to the set of answers $(5-2,6-2)$ or $(7-2,8-2)$. The risk-free rate of return corresponds to the set of answers (5-2, 6-1) or (7-2, 8-1). The market return corresponds to the set of answers (5-1, 6-1) or (7-1, 8-1). Finally, answering (5-1, 6-2) or (7-1, 8-2) is inconsistent. The "Probability" column reports one-sided p-values of the normal approximation for the binomial test (expected proportion of 0.25). Panel A presents the results for the marginal investment (1,000 euro), and Panel B presents the results for the total investment (20,000 euro).

Panel A. Marginal investment.

\begin{tabular}{|c|c|c|c|c|c|c|c|c|c|}
\hline \multirow[t]{2}{*}{ Benchmark } & \multicolumn{3}{|c|}{$\begin{array}{l}\text { Subjects who chose probability of } \\
\text { loss or expected value of loss }\end{array}$} & \multicolumn{3}{|c|}{$\begin{array}{c}\text { Subjects who chose semi-variance of } \\
\text { returns }\end{array}$} & \multicolumn{3}{|c|}{ All respondents } \\
\hline & $\begin{array}{l}\text { Number of } \\
\text { observations }\end{array}$ & Percent & Probability & $\begin{array}{c}\text { Number of } \\
\text { observations }\end{array}$ & Percent & Probability & $\begin{array}{c}\text { Number of } \\
\text { observations }\end{array}$ & Percent & Probability \\
\hline Initial investment & 84 & 31.46 & 0.007 & 67 & 25.77 & 0.387 & 151 & 28.65 & 0.026 \\
\hline Risk-free rate of return & 56 & 20.97 & 0.064 & 37 & 14.23 & 0.000 & 93 & 17.65 & 0.000 \\
\hline Market return & 81 & 30.34 & 0.022 & 128 & 49.23 & 0.000 & 209 & 39.66 & 0.000 \\
\hline Inconsistent results & 46 & 17.23 & 0.002 & 28 & 10.77 & 0.000 & 74 & 14.04 & 0.000 \\
\hline Total & 267 & 100 & & 260 & 100 & & 527 & 100 & \\
\hline
\end{tabular}


Panel B. Total investment.

\begin{tabular}{|c|c|c|c|c|c|c|c|c|c|}
\hline \multirow[t]{2}{*}{ Benchmark } & \multicolumn{3}{|c|}{$\begin{array}{l}\text { Subjects who chose probability of } \\
\text { loss or expected value of loss }\end{array}$} & \multicolumn{3}{|c|}{$\begin{array}{c}\text { Subjects who chose semi-variance of } \\
\text { returns }\end{array}$} & \multicolumn{3}{|c|}{ All respondents } \\
\hline & $\begin{array}{l}\text { Number of } \\
\text { observations }\end{array}$ & Percent & Probability & $\begin{array}{l}\text { Number of } \\
\text { observations }\end{array}$ & Percent & Probability & $\begin{array}{l}\text { Number of } \\
\text { observations }\end{array}$ & Percent & Probability \\
\hline Initial investment & 62 & 30.39 & 0.038 & 64 & 36.99 & 0.000 & 126 & 33.42 & 0.000 \\
\hline Risk-free rate of return & 33 & 16.18 & 0.002 & 19 & 10.98 & 0.000 & 52 & 13.79 & 0.000 \\
\hline Market return & 53 & 25.98 & 0.373 & 67 & 38.73 & 0.000 & 120 & 31.83 & 0.001 \\
\hline Inconsistent results & 56 & 27.45 & 0.209 & 23 & 13.29 & 0.000 & 79 & 20.95 & 0.035 \\
\hline Total & 204 & 100 & & 173 & 100 & & 377 & 100 & \\
\hline
\end{tabular}




\section{Table VIII. Demographic profiles and (the lack of) investment choices.}

This table presents estimation results of a logit model, where the dependent variable is equal to 1 when the respondents replied either " 3 " (I am indifferent) or 4 (The question is not clear for me) to at least one of the questions 1 to 4 of the survey (for the questions on an investment of 1,000 euro) and 0 otherwise. Panel A presents answers of all respondents. Panel B presents only answers of individuals who have investments in risky assets (excluding savings accounts and investment mortgages/life annuities). Values of z-statistic are in parentheses. Asterisks indicate significance levels of z-statistics: ${ }^{*} 10$ percent; ${ }^{* *} 5$ percent; ${ }^{* * *} 1$ percent.

\begin{tabular}{|c|c|c|c|c|c|c|c|}
\hline Constant & Age below 55 & Gender: Male & $\begin{array}{l}\text { University or } \\
\text { college } \\
\text { education }\end{array}$ & $\begin{array}{l}\text { Monthly gross } \\
\text { income above } \\
2000 \text { euro }\end{array}$ & $\begin{array}{l}\text { Number of } \\
\text { observations }\end{array}$ & LR statistic & $\begin{array}{c}p \text {-value of LR } \\
\text { statistic }\end{array}$ \\
\hline \multicolumn{8}{|l|}{$\begin{array}{l}\text { Panel A. All } \\
\text { respondents }\end{array}$} \\
\hline $\begin{array}{l}0.386^{* * *} \\
(4.027)\end{array}$ & $\begin{array}{l}-0.251^{* * *} \\
(-2.731)\end{array}$ & $\begin{array}{l}-0.175^{*} \\
(-1.818) \\
\end{array}$ & $\begin{array}{c}-0.122 \\
(-1.307) \\
\end{array}$ & $\begin{array}{l}-0.212^{* *} \\
(-2.075)\end{array}$ & 2207 & 26.495 & 0.000 \\
\hline \multicolumn{8}{|l|}{$\begin{array}{c}\text { Panel B. } \\
\text { Investors only }\end{array}$} \\
\hline $\begin{array}{c}0.183 \\
(1.060)\end{array}$ & $\begin{array}{l}-0.274^{*} \\
(-1.806)\end{array}$ & $\begin{array}{c}-0.506^{* * *} \\
(-3.022)\end{array}$ & $\begin{array}{c}0.041 \\
(0.265)\end{array}$ & $\begin{array}{c}0.011 \\
(0.065)\end{array}$ & 785 & 13.028 & 0.011 \\
\hline
\end{tabular}




\section{Table IX. Risk perceptions and holding of risky assets.}

This table presents estimation results of a logit model, where the dependent variable is equal to 1 when the respondents own particular risky assets and 0 otherwise. We use the preference for a certain risk measure, as measured by choosing this risk measure against the other three risk measures in Questions 1 to 4, as explanatory variables, and respondents' socio-demographic characteristics as control variables. Values of z-statistic are in parentheses. Asterisks indicate significance levels of z-statistics: ${ }^{*} 10$ percent; ${ }^{* *} 5$ percent; ${ }^{* * *} 1$ percent.

Dependent variable: Risky assets owned

\begin{tabular}{|c|c|c|c|}
\hline & $\begin{array}{l}\text { Exchange-traded } \\
\text { stocks }\end{array}$ & Investment funds & Corporate bonds \\
\hline Constant & $\begin{array}{l}-2.441^{* * *} \\
(-13.098)\end{array}$ & $\begin{array}{l}-1.250^{* * *} \\
(-9.125)\end{array}$ & $\begin{array}{l}-3.231^{* * *} \\
(-10.903)\end{array}$ \\
\hline $\begin{array}{l}\text { Q.1 = } 1 \text { (Probability of } \\
\text { loss) }\end{array}$ & $\begin{array}{c}0.039 \\
(0.246)\end{array}$ & $\begin{array}{l}0.355^{* * *} \\
(2.885)\end{array}$ & $\begin{array}{l}0.663^{* * *} \\
(2.669)\end{array}$ \\
\hline Q.2 = 1 (Semi-variance) & $\begin{array}{l}0.328^{* *} \\
(2.301)\end{array}$ & $\begin{array}{l}0.266^{* *} \\
(2.325)\end{array}$ & $\begin{array}{l}-0.110 \\
(-0.429)\end{array}$ \\
\hline $\begin{array}{l}\text { Q.3 = } 1 \text { (Expected value } \\
\text { of loss) }\end{array}$ & $\begin{array}{c}0.056 \\
(0.329)\end{array}$ & $\begin{array}{c}-0.075 \\
(-0.546)\end{array}$ & $\begin{array}{l}-0.076 \\
(-0.256)\end{array}$ \\
\hline Q.4 = 1 (Variance) & $\begin{array}{c}0.063 \\
(0.424)\end{array}$ & $\begin{array}{c}0.026 \\
(0.214)\end{array}$ & $\begin{array}{c}0.360 \\
(1.452)\end{array}$ \\
\hline Male & $\begin{array}{l}0.646^{* * *} \\
(3.997)\end{array}$ & $\begin{array}{c}0.159 \\
(1.305)\end{array}$ & $\begin{array}{l}-0.191 \\
(-0.701)\end{array}$ \\
\hline Age below 55 & $\begin{array}{l}-0.337^{* *} \\
(-2.410)\end{array}$ & $\begin{array}{l}-0.162 \\
(-1.432)\end{array}$ & $\begin{array}{l}-0.878^{* * *} \\
(-3.731)\end{array}$ \\
\hline $\begin{array}{l}\text { University or college } \\
\text { education }\end{array}$ & $\begin{array}{l}0.639^{* * *} \\
(4.409)\end{array}$ & $\begin{array}{l}0.423^{* * *} \\
(3.735)\end{array}$ & $\begin{array}{l}0.548^{* *} \\
(2.162)\end{array}$ \\
\hline Income above 2000 euro & $\begin{array}{l}0.344^{* *} \\
(2.132)\end{array}$ & $\begin{array}{l}0.592^{* * *} \\
(4.714)\end{array}$ & $\begin{array}{l}0.580^{* *} \\
(1.995)\end{array}$ \\
\hline Number of observations & 1618 & 1618 & 1618 \\
\hline LR statistic & 87.256 & 89.903 & 35.203 \\
\hline$p$-value of LR statistic & 0.000 & 0.000 & 0.000 \\
\hline
\end{tabular}

